\title{
Calcareous nannoplankton in the Upper Jurassic marine deposits of the Bohemian Massif: new data concerning the Boreal-Tethyan communication corridor
}

\author{
Katarína HOLCOVÁ ${ }^{1},{ }^{*}$ and Magdalena HOLCOVÁ ${ }^{1}$ \\ 1 Charles University in Prague, Institute of Geology and Palaeontology, Albertov 6, 12843 Praha 2, Czech Republic
}

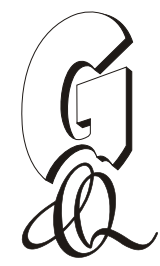

\begin{abstract}
Holcová, K., Holcová, M., 2016. Calcareous nannoplankton in the Upper Jurassic marine deposits of the Bohemian Massif: new data concerning the Boreal-Tethyan communication corridor. Geological Quarterly, 60 (3): 624-636, doi: 10.7306/gq. 1282

Calcareous nannoplankton assemblages from the Jurassic relict deposits in the northern part of the Bohemian Massif are described here for the first time. They are generally of low diversity and dominated by watznaueriaceans. Some of them are diagenetically affected, probably due to dolomitisation. Calcareous nannoplankton enables the stratigraphical range of the Northern Bohemia Jurassic succession to be extended to the Tithonian by reference to the stratigraphical range of Jurassic platform sequences in Central Poland and the eastern part of the Bohemian Massif. The Oxfordian-Kimmeridgian nannofossil assemblages indicate a generally oligotrophic condition of the restricted sea with episodic fluvial input containing terrestrial nutrients. The character of the upper part of the water column was generally uniform and did not reflect variability at the sea-floor expressed by lithofacies diversity. The palaeoenvironment interpreted for the famous former palaeontological locality "Sternberk Quarry" was characterized by a higher nutrient content and more stable environment. The Tithonian nannofossil assemblages contain warm-water Tethyan taxa which suggest south-north migration of nannoplankton due to warming during the Jurassic-Cretaceous boundary interval.
\end{abstract}

Key words: calcareous nannoplankton, Late Jurassic, North Bohemian Massif, biostratigraphy, palaeoecology.

\section{INTRODUCTION}

The Jurassic marine deposits of the northern part of the Bohemian Massif are preserved in a few small outcrops associated with the Lusatian Fault (Eliáš, 1981). However, these relicts may have palaeogeographical significance in recording the communication corridor between Boreal and Sub-Boreal areas and the Tethyan Realm (Atrops et al., 1993; Matyja and Wierzbowski, 1994, 2000).

Though fossils from these outcrops, comprising diverse fossil assemblages (ammonites, belemnites, brachiopods, bivalves, sponges, echinoderms, bryozoans, annelids and fish) are stored in museum collections, only the ammonites have been studied, mostly in the 19th century (Lenz, 1870; Bruder, 1881, 1882, 1885, 1886).

Using these data from the 19th century as well as the results of geological mapping from the 1960s (Kopecký et al., 1963), the geology of the northern Bohemia Jurassic units was described in syntheses of the Bohemian Massif (Eliáš, 1981; Suk et al., 1984; Chlupáč et al., 2002). The newest data have been published by Hrbek (2014) who suggested an Upper Oxfordian and Lower Kimmeridgian age of the Jurassic relicts on the basis of aulacostephanid ammonites. The presence of

\footnotetext{
* Corresponding author, e-mail: holcova@natur.cuni.cz
}

Received: December 1, 2015; accepted: January 20, 2016; first published online: March 1, 2016
Boreal and Sub-Boreal taxa in the Northern Bohemian Massif probably reflects the equatorwards migration of cold-water ammonites around the Oxfordian-Kimmeridgian boundary. Taxa occurring in Northern Bohemia show affinity to those occurring in the Polish Jura Chain and southern Germany which supports the presence of a seaway between these areas across the Bohemian Massif (Matyja and Wierzbowski, 1995).

Our study describes the first finding of Jurassic calcareous nannoplankton in the Bohemian Massif. The aim of the work is to describe these nannofossil assemblages and discuss their biostratigraphical, palaeogeographical and palaeoecological significance.

\section{GEOLOGICAL SETTING}

The Jurassic strata in Northern Bohemia are associated with the Lusatian Fault (Eliáš, 1981). During the younger phase of the Saxonic tectonic event, the re-activation of the Lusatian tectonic zone thrust the Cadomian, Paleozoic and Jurassic rocks over the Cretaceous ones (Eliáš, 1981). The Late Paleozoic-Mesozoic sedimentary succession overlay the Upper Proterozoic and Paleozoic metamorphic rocks and granitoids of Lugicum (Chlupáč and Štorch, 1992). The Middle Jurassic Brtníky Formation built up predominantly of sandy, fossil-poor clastic deposits was formed after deposition of terrigenous Carboniferous and Permian sediments and a long hiatus (Suk et al., 1984). Its sedimentation probably corresponds to the Callovian (Bruder, 1881, 1882; Kopecký et al., 1963; Eliáš, 
1981; Chlupáč et al., 2002). The overlying Doubice Formation is built up of a carbonate-siliciclastic succession that was deposited in a deep shelf environment. Based on data from outcrops that no longer exist, a sedimentary succession formed of organodetrital limestones, marly limestones, cherts, marls, and sandy rocks can be reconstructed (Fig. 1; Kopecký et al., 1963; Eliáš, 1981; Suk et al., 1984; Hrbek, 2014). Unfortunately, a modern detailed sedimentological analysis of the Upper Jurassic facies of Northern Bohemia is not possible because of scarcity of outcrop. Due to influence of the Lusatian tectonic zone and Cenozoic volcanism, the Doubice Formation was weakly to strongly dolomitised (Eliáš, 1981). Existing exposures exhibit only strongly dolomitised carbonate with extremely rare macrofossils (Hrbek, 2014; Košták, pers. comm., 2015). These include old quarries near Doubice classified as a representative geosite of the Central Europe Jurassic by Alexandrowicz (1999).

\section{MATERIAL AND METHODS}

The lack of a continuous section of Jurassic deposits in Northern Bohemia (with the exception of strongly dolomitised rocks) led us to develop two indirect ways of reconstructing the depositional history for the purposes of nannoplankton investigation (Fig. 2): (1) rock material from the former Šternberk Quarry near Brtníky is preserved in the collections of the National Museum, Prague (NM-N) and the Institute of Geology and Palaeontology, Faculty of Science, Charles University, Prague (CIGP) (20 samples). Though the quarry is equated with the old quarry "Brtníky" in the list of geosites registered by the Czech Geological Survey (http://lokality.geology.cz), only strongly dolomitised carbonates without macrofossils are exposed there nowadays (Košták, pers. comm., 2015). (2) Fragments of Jurassic rocks from the creek below "Peškova stráň" (Pešek's Hillside) near the village of Kyjov represent the most diverse source of Upper Jurassic lithotypes today (46 samples).

Six lithotypes have been distinguished among fragments from "Peškova stráň": (1) light coarse micritic limestones (6 fragments), (2) light fine micritic limestones (21 fragments), (3) dark fine limestones (5 fragments), (4) light coarse marly limestone (8 fragments), (5) light coarse organodetrital limestone (5 fragments), (6) light fine marly limestone (1 fragment). These lithotypes could be equated with the Doubice Formation, though the time succession of lithotypes cannot be determined and correlation with section described in 19th century (Fig. 1) is impossible. Unfortunately, no fine clastic deposits which could be more suitable for preservation of calcareous nannofossils were found either in the museums or in the field.

Nannoplankton was studied using the simple smear slides in normal and polarized light. Smear slides were prepared from powdered sediment without centrifuging, cleaning and concentration in order to retain the original sediment composition following the methodology of Casellato (2008). Calcareous nannofossils were investigated using a light polarizing microscope, at $1000 \times$ magnification. The nannofossil abundance was expressed as the number of nannofossils per field of view averaged for ca. 50 fields of view per sample. Besides the quantitative measure of nannofossil abundance the semi-quantitative scale for Late Jurassic nannoplankton was also applied (Casellato, 2010): abundant (A): >10 specimens per field of view; common $(C)$ : 1-10 specimens per 1 field of view; few $(F)$ : 1 specimen per $1-10$ fields of view; rare $(R)$ : 1 specimen per 11-50 fields of view; barren (B): no specimen was found.

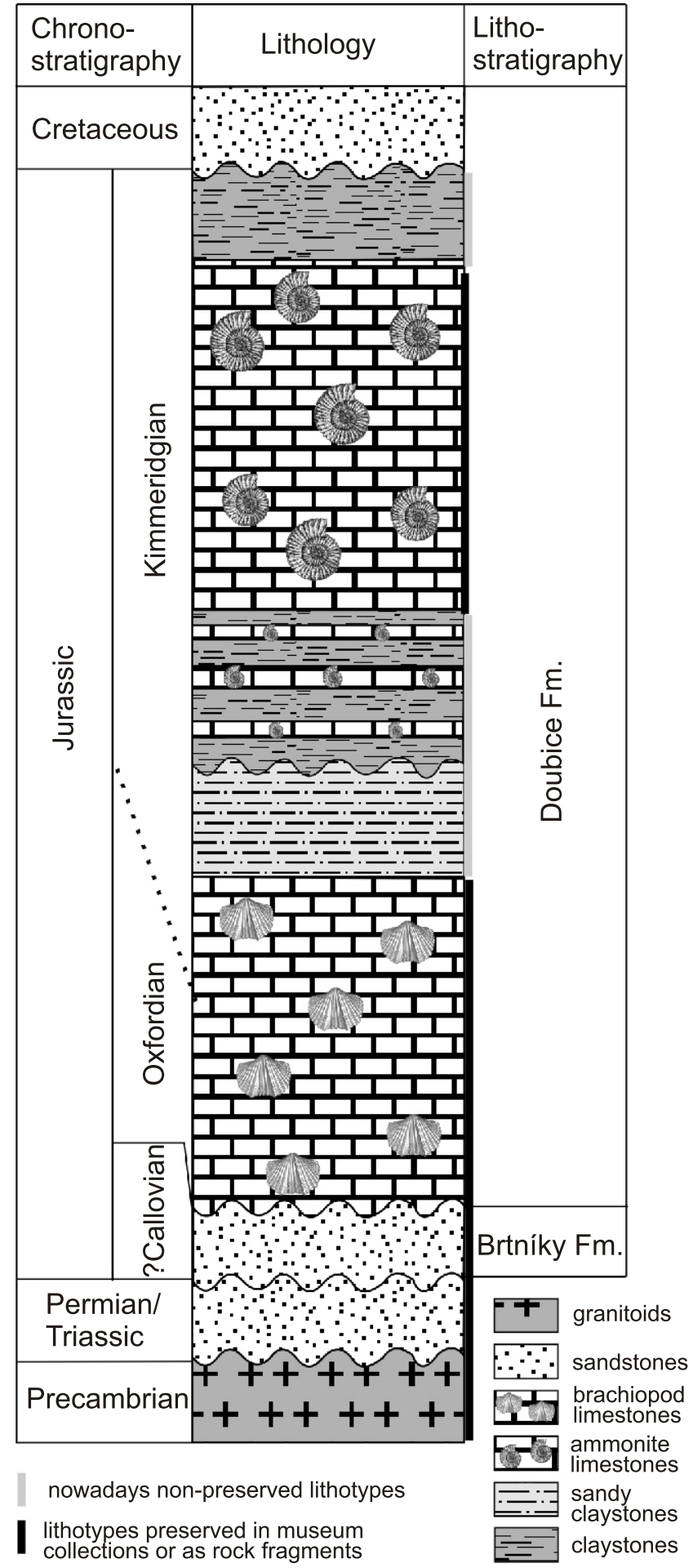

Fig. 1. Idealized lithological succession of Jurassic deposits from Northern Bohemia (summarized from data of Kopecký et al., 1963; Eliáš, 1981; Suk et al., 1984; Hrbek, 2014)

The scanning electron microscope (SEM) was used to study the preservation of the nannofossils. Calcareous nannoplankton was concentrated for SEM study using the decanting method with electrolyte (35 g of sodium hexametaphosphate, $8 \mathrm{~g}$ of sodium carbonate in $1 \mathrm{I}$ of distilled water). Approximately $1 \mathrm{~g}$ of powdered rock sample was shaken with $10 \mathrm{ml}$ of electrolyte and, after 40 minutes, the liquid 


\section{RESULTS}

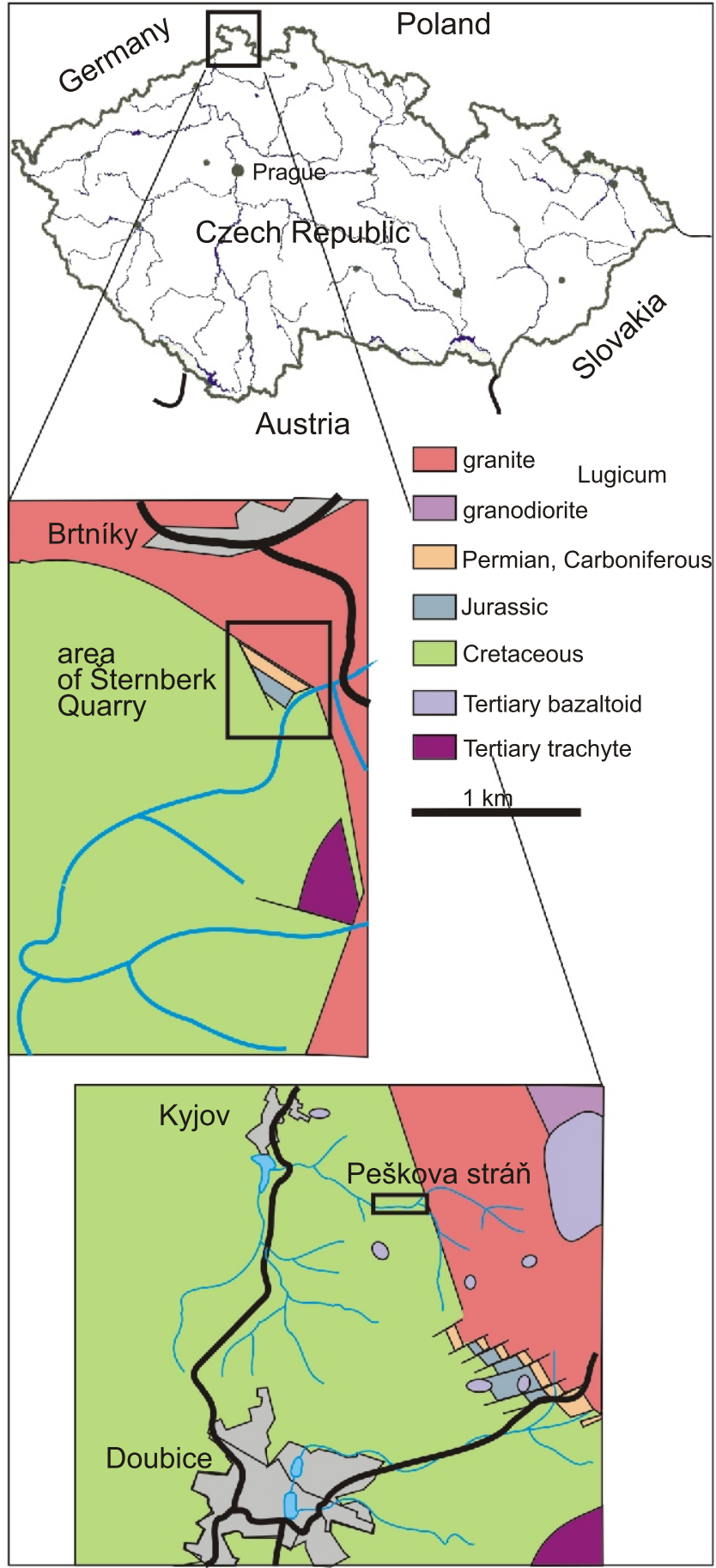

Fig. 2. Location of samples studied

Geological situation from www.geology.cz

was decanted. This process was repeated five times. Then a suspension was mixed once again and, three minutes after mixing, a drop of liquid was used for observation under SEM.

For evaluation of nannofossil preservation, the classification of Roth (1983) was applied: (1) E1 - slight etching, E2 moderate etching, E3 - strong dissolution for classification of etching, and (2) $\mathrm{O} 1$ - slight overgrowth, $\mathrm{O} 2$ - moderate overgrowth, $\mathrm{O} 3$ - strong overgrowth for evaluation of overgrowth.
PRESERVATION OF NANNOFOSSILS

SEM study showed better preservation of nannoplankton in the former Šternberk Quarry by comparison with rock fragments from "Peškova strán̆" (Figs. 3 and 4). Though some specimens have serrate outlines (e.g., Fig. 3E, T, AC, BL, ML, BM, BQ) as well as broken central areas (Fig. 3AX), most nannofossils from Sternberk Quarry shows intact outlines and structures in the central area, therefore preservation can be classified as category $E 1$ - slight etching (Roth, 1983). Strongly diagenetically influenced assemblages composed only of dissolution-resistant large Watznaueria with serrate outlines (e.g., Fig. 4A, B, G, H) were found in rock fragments from "Peškova stráň". They are classified as category E3 - strong dissolution (Roth, 1983). Even the nannofossils from the best preserved, diverse assemblages showed dissolution when studied by SEM (Fig. 4AO-AV), their preservation corresponding with category E2 (moderate etching). Figure 5 shows that there is no correlation between lithological type and nannoplankton preservation. In particular, the expected correlation of well-preserved nannofossils with fine and marly lithotypes in contrast to badly-preserved nannoplankton with coarse carbonates has not been observed.

\section{ABUNDANCE OF NANNOFOSSILS}

All samples from Šternberk Quarry and most samples from rock fragments from "Peškova stráń" (88\%) contain calcareous nannoplankton. Average nannofossil abundances in individual samples vary from 0 to 56 specimens/field of view in fragments from "Peškova stráň" and from 0.5 to 9.2 specimens/field of view in Šternberk Quarry samples (Fig. 6A, B).

No correlation between the six recognized lithotypes and calcareous nannoplakton abundance has been observed (Fig. 6B). The Kruskall-Wallis test (Palentological Software PAST; Hammer et al., 2001) confirmed the hypothesis about no statistically significant differences in nannofossil abundances in individual lithotypes $(p<0.001)$.

Additionally, the nannofossil abundances were classified using Casellato's semiquantitative abundance scheme (Casellato, 2010) defined for Late Jurassic nannofossils (Fig. 6C). Visual evaluation of the histogram suggests the highest abundances for dark fine limestones and light coarse marly limestones. However, the evaluation is not fully reliable due to the small numbers of samples from some lithotypes (mainly fine marly limestones).

\section{DIVERSITY OF NANNOFOSSIL ASSEMBLAGES}

In total, nineteen species were determined, with number of species in individual samples varying from two to eight. Watznaueria spp. predominate in all assemblages while the ratio between $W$. communis, $W$. barnesiae, $W$. fossacincta and $W$. britannica varies. Cyclagelosphaera margerelii, and watznauerias are abundant. The relative abundances of small Watznaueria spp., large Watznaueria manivitiae and Cyclagelosphaera deflandrei differ between individual samples, suggesting they are common, while other species are rare (Appendix $1^{*}$ ).

Using the results of cluster analyses (Ward's method; correlation coefficient $=0.9253$ ) supported by results of non-metric multidimensional scaling ( $\mathrm{n}-\mathrm{MMDS}$; stress $=0.096)$ seven assemblages were distinguished (Fig. 7A, B): 

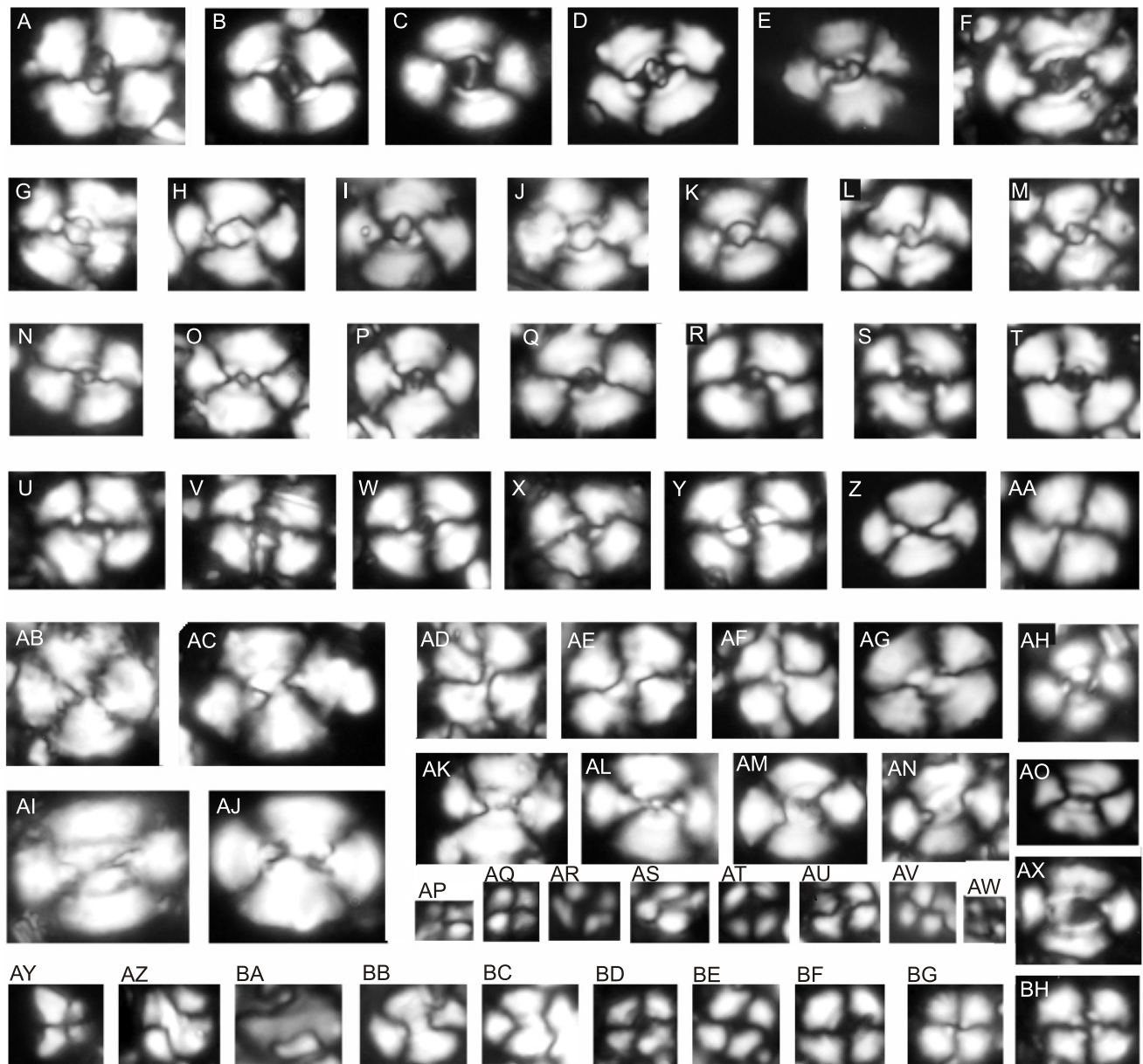

$\mathrm{BC}$

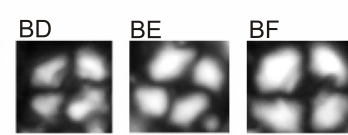

BG
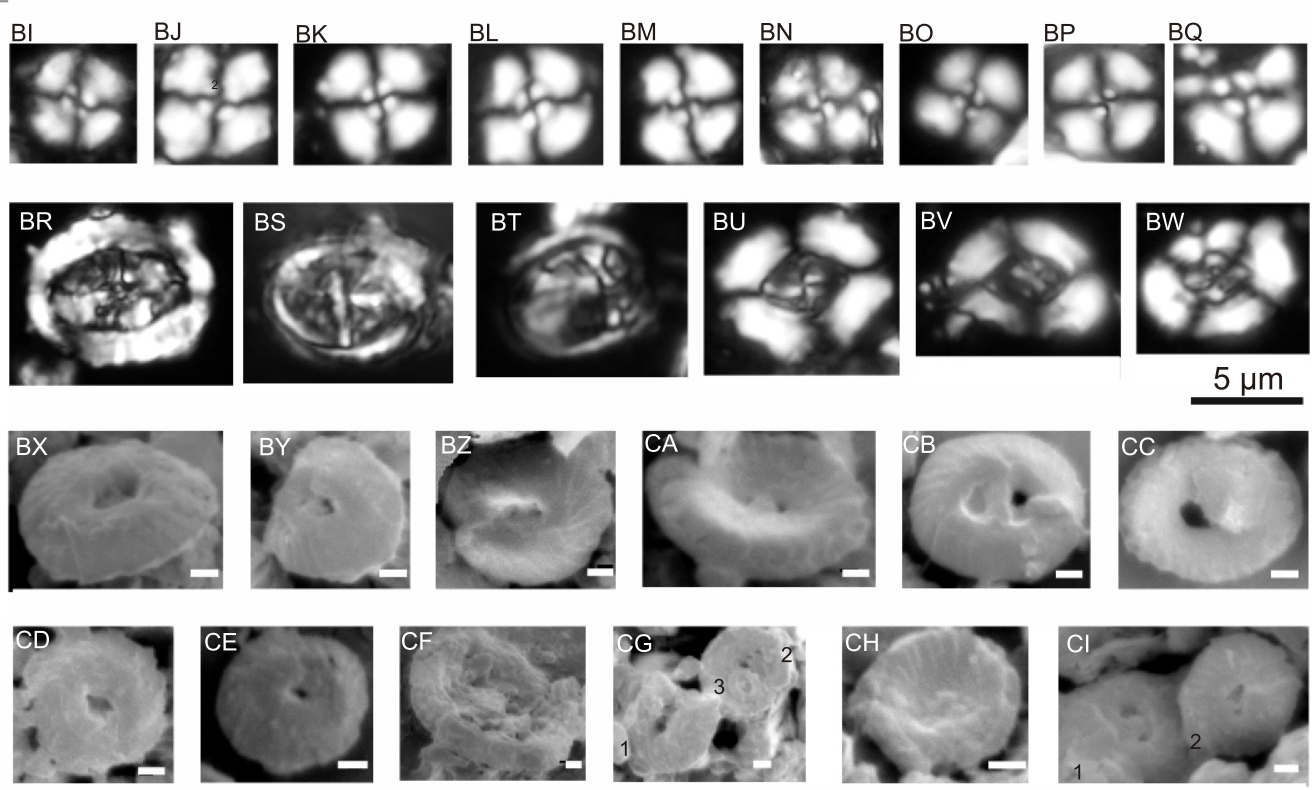

Fig. 3. Calcareous nannoplankton from the former Šternberk Quarry

A-T - morphological variability of Watznaueria britannica (Stradner, 1963) Reinhardt, 1964; U, W - Watznaueria fossacincta (Black, 1971) Bown in Bown \& Cooper, 1989; X, Y - Watznaueria barnesiae (Black in Black \& Barnes, 1959) Perch-Nielsen, 1968; Z-AO - Watznaueria communis Reinhardt, 1964; AP-AW - small indeterminable coccoliths; AX - Watznaueriaceae with broken central area; AY - strongly diagenetically affected specimen (indeterminable); AZ-BC - Assipetra sp.; BD, BE - small Watznaueria fossacincta (Black, 1971) Bown in Bown \& Cooper, 1989; BF-BQ - Cyclagelosphaera margerelii Noël, 1965; BR - Retecapsa escaigii (Noël, 1965) Young \& Bown 2014; BS, BT - Axopodorhabdus cylindratus (Noël, 1965) Wind and Wise in Wise and Wind, 1977; BU, BV - Lotharingius sigillatus (Stradner, 1961); BW - Helenea chiastia Worsley, 1971; BX-CC - Watznaueria britannica (Stradner, 1963) Reinhardt, 1964; CD, CE Cyclagelosphaera margerelii Noël, 1965; CF - Retecapsa octofenestrata (Bralower in Bralower et al., 1989) Bown in Bown \& Cooper, 1998; CG - corroded Watznaueria britannica, 2. Retecapsa octofenestrata, 3. small Watznaueriaceae; CH - Cyclagelosphaera sp.; CI: 1 Watznaueria britannica (Stradner, 1963) Reinhardt, 1964, 2- Watznaueria sp.; A-BW - optical microscope, polarized light, black scale bar $(5 \mu \mathrm{m})$; $\mathbf{B X}-\mathbf{C l}$ - scanning electron microscope, length of scale bar $1 \mu \mathrm{m}$ 

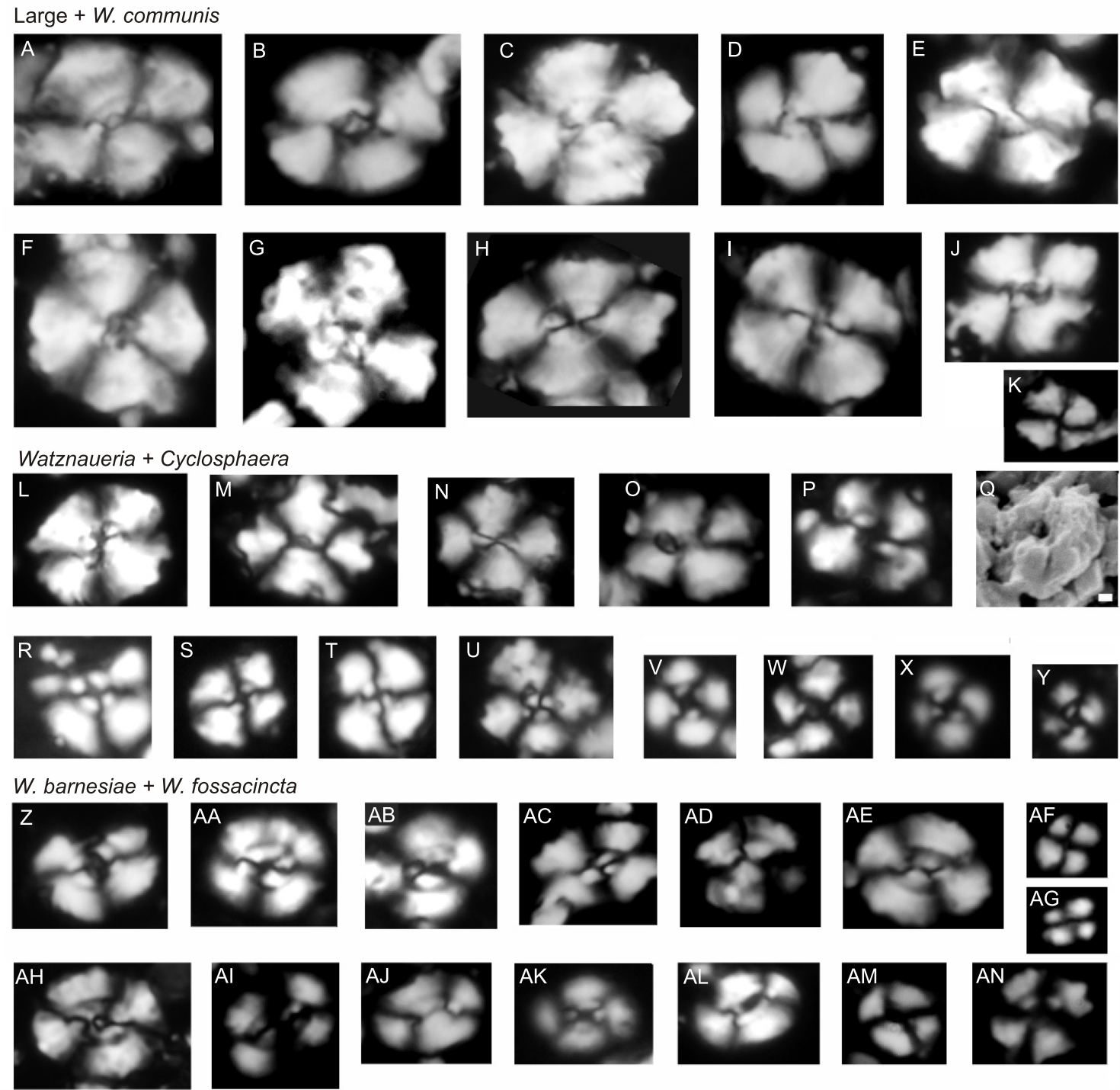

Diversified
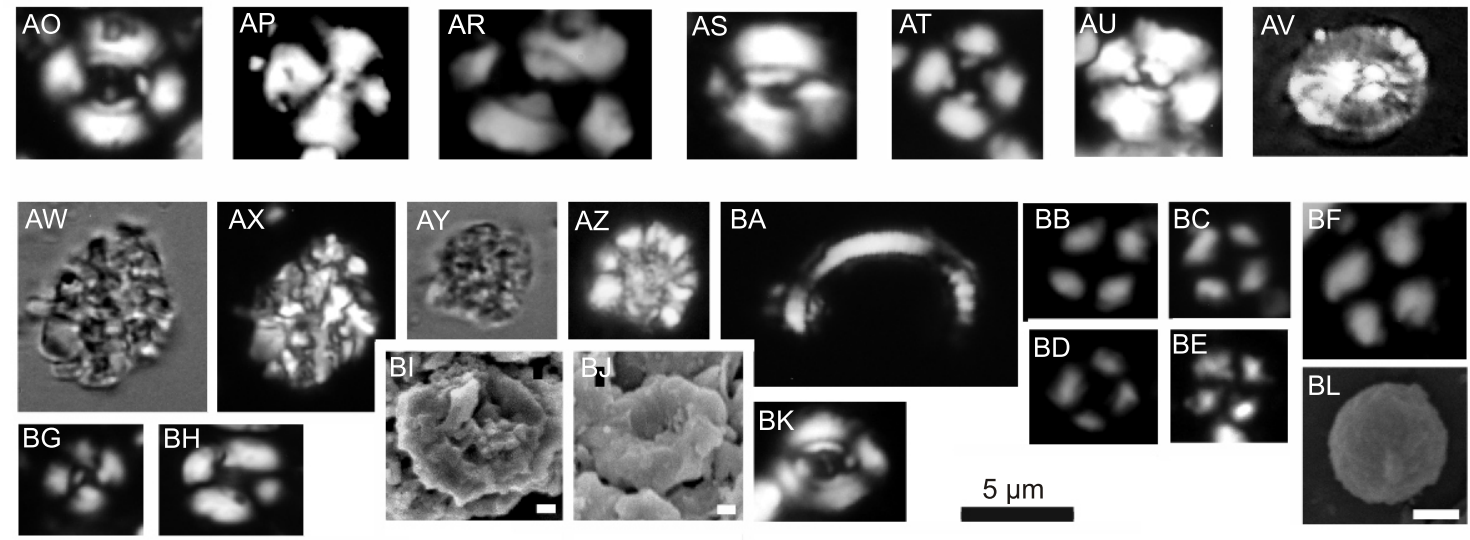

Fig. 4. Calcareous nannoplankton from rock fragments from "Peškova stráň” (Pešek's Hillside) near the village of Kyjov

A-K - assemblage with large nannofossils mainly W. communis: A-E, J - Watznaueria communis Reinhardt, 1964, F - Cyclagelosphaera argoensis Bown, 1992, G - Cyclagelosphaera deflandrei (Manivit, 1966) Roth, 1973, H, I - large Watznaueria barnesiae (Black in Black \& Barnes, 1959) Perch-Nielsen, 1968, K - small Watznaueria sp.; L-Y - assemblage with Watznaueria spp. and Cyclagelosphaera margerelii: L-O - Watznaueria barnesiae (Black in Black \& Barnes, 1959) Perch-Nielsen, 1968, P - Watznaueria fossacincta (Black, 1971) Bown in Bown \& Cooper, 1989, Q-Y - Cyclagelosphaera margerelii Noël, 1965; Z-AN - assemblage dominated by W. barnesiae and W. fossacincta: Z, AB-AJ, AL, AM - Watznaueria barnesiae (Black in Black \& Barnes, 1959) Perch-Nielsen, 1968, AA, AK, AN - Watznaueria fossacincta (Black, 1971) Bown in Bown \& Cooper, 1989; AO-BL - diverse assemblage: AO, BK - Watznaueria britannica (Stradner, 1963) Reinhardt, 1964, AP - Watznaueria communis Reinhardt, 1964, AR, AS - Watznaueria biporta Bukry, 1969, AT, BG, BJ - Cyclagelosphaera margerelii Noël, 1965, AV - Biscutum constans (Górka, 1957) Black in Black and Barnes, 1959, AW-AZ - Nannoconus sp., BA - Biscutum sp., BB-BD - Diazomatolithus lehmanii Noël, 1965, BF, BH - Watznaueria sp., BI - Retecapsa octofenestrata (Bralower in Bralower et al., 1989) Bown in Bown \& Cooper, 1998, BL - Orthopithonella sp.; A-P, R-BH, BK - optical microscope, polarized light with the exception of AW, AY (normal light), black scale bar $(5 \mu \mathrm{m})$; BI, BJ, BL - scanning electron microscope; length of scale bar $1 \mu \mathrm{m}$ 


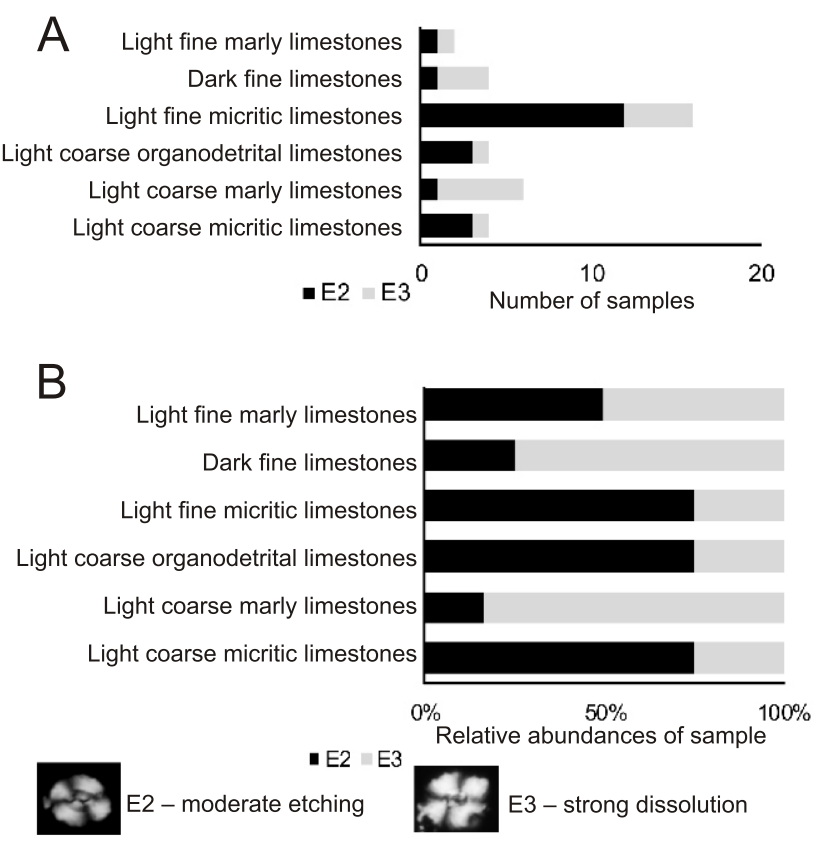

Fig. 5. Nannoplankton preservation in fragments from "Peškova strán̆" (Pešek's Hillside) in relation to lithotypes

The etching description of (Roth, 1983) was used;

A - absolute abundances, $\mathbf{B}$ - relative abundances

1. An assemblage dominated by $W$. britannica characterizes samples from Šternberk Quarry. It is one of the highest diversity in the material studied and contains the best preserved nannofossils;

2. Similar to assemblage (1) but of lower diversity. W. britannica is accompanied almost solely by $W$. barnesiae and $W$. fossacincta. The assemblage was recorded only from Šternberk Quarry;

3. A diverse assemblage composed of well-preserved nannofossils occurs in rock fragments from "Peškova stráň";

4. An assemblage dominated by $W$. barnesiae and $W$. fossacincta contains 4-5 species. The nannofossils are moderately preserved. This type of assemblage is characteristic of rock fragments from "Peškova stráń";

5. An assemblage with Watznaueria spp. and Cyclagelosphaera margerelii contains about 5 species and the nannofossils are moderately preserved. The assemblage was recorded from both Šternberk Quarry and "Peškova stráń";

6. An assemblage contains moderately to badly preserved nannofossils dominated by $W$. communis. It reaches lower diversity (3-4 species) and occurs in "Peškova stráň";

\section{Fig. 6. Relation between nannofossil abundance and lithotype}

A - histogram of nannofossil abundances expressed as number of nannofossils in visual field of microscope averaged for ca. 50 fields; B - lower abundances are figured in detail and abundances from Šternberk Quarry and rock fragments are compared; C - distribution of nannofossil abundances in individual lithotypes using quantitative values of abundances and ratios of samples with and without calcareous nannoplankton; D, E - distribution of nannofossil abundances in individual lithotypes using the semiquantitative abundance scale of Casellato (2010), numbers of samples are expressed as absolute values $(D)$, and relatively as percentages $(E)$
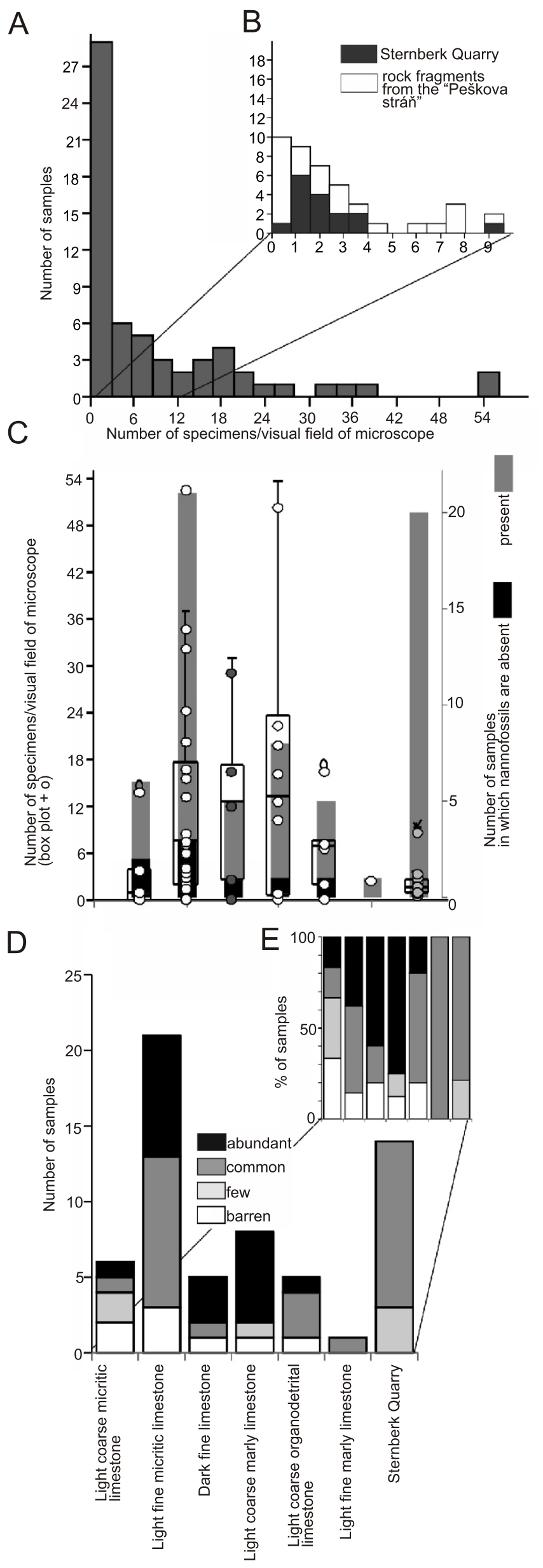

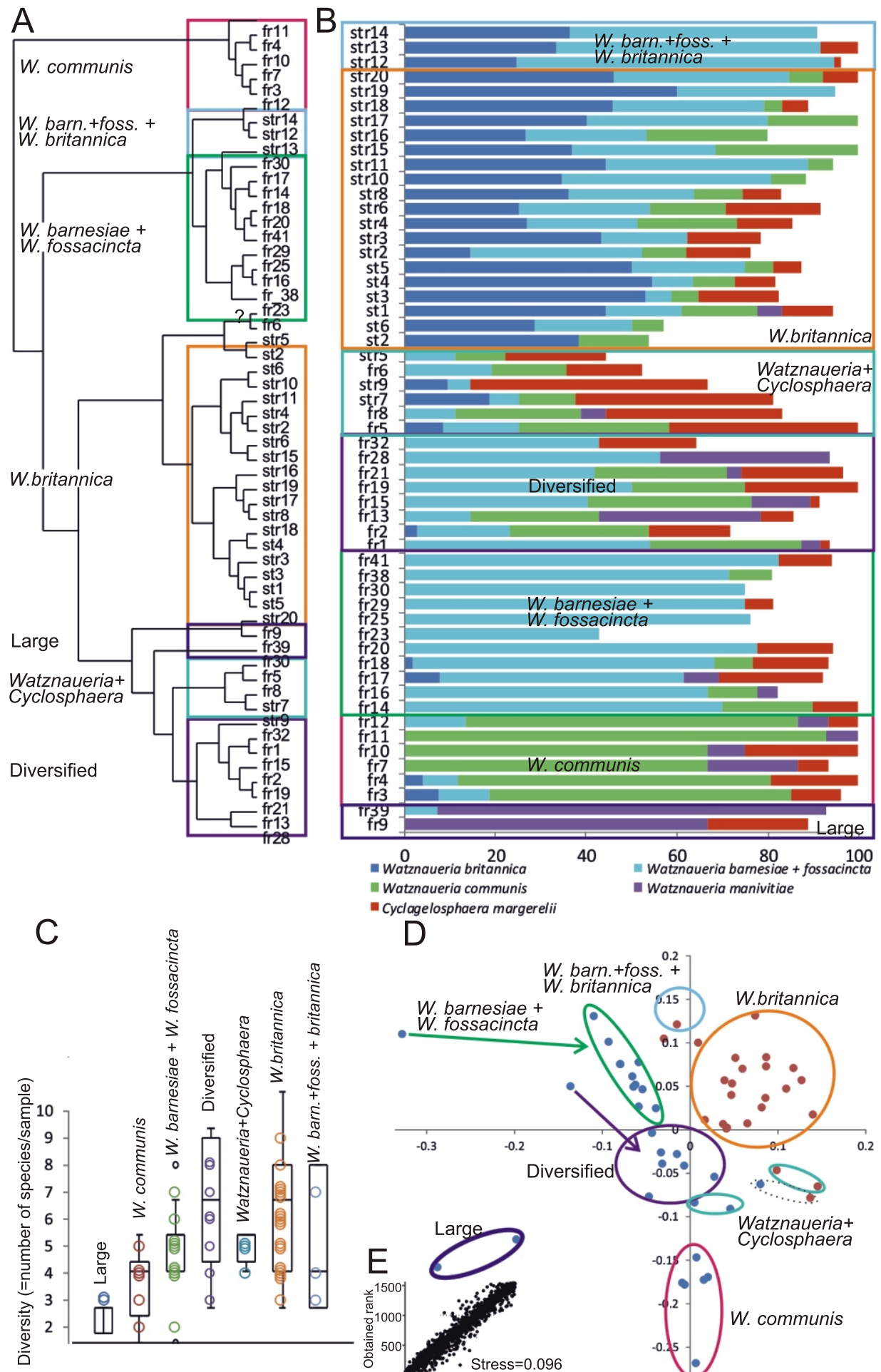

D
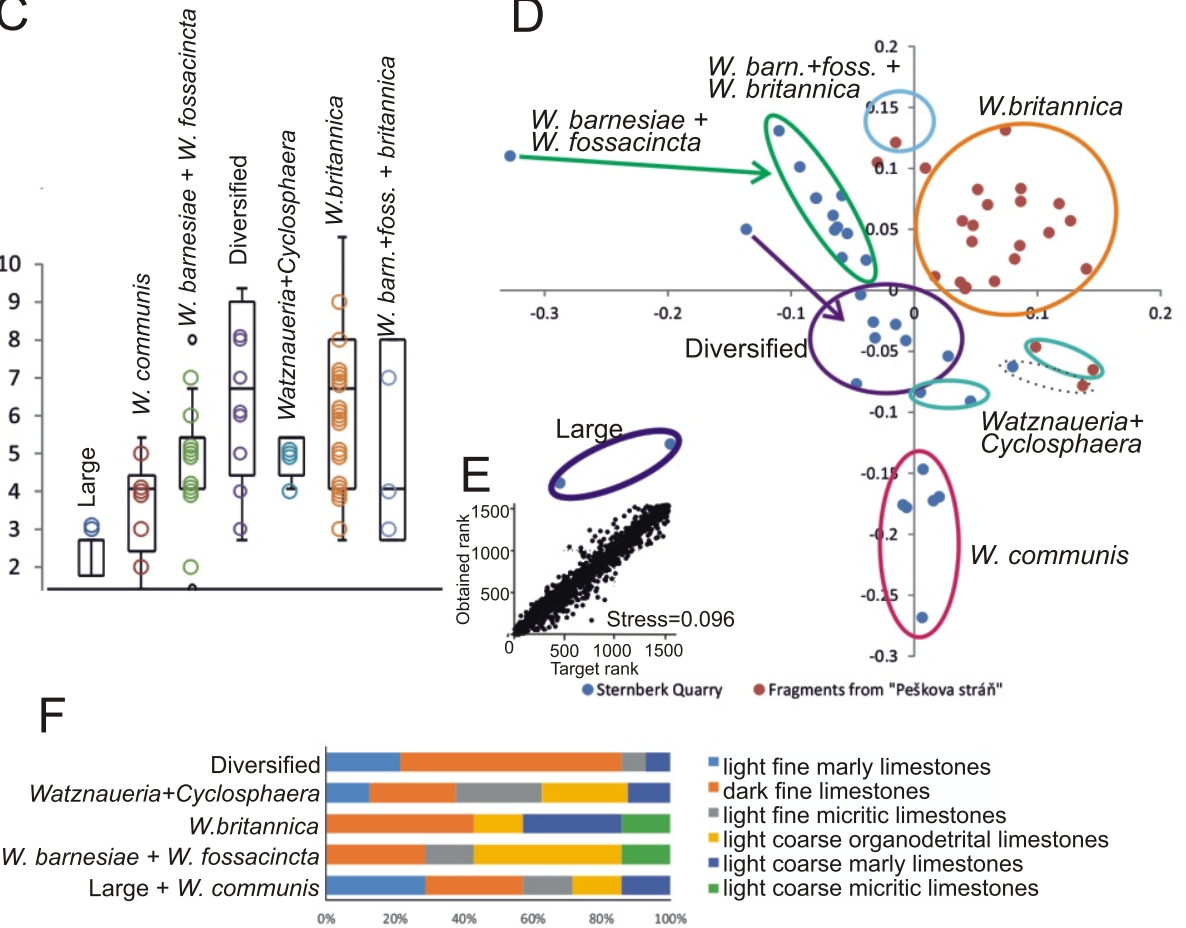

Fig. 7. Calcareous nannoplankton assemblages defined from cluster analyses (Ward method, A) and non-metric multidimensional scaling (D), relative abundances of dominant taxa in assemblages (B), diversity of individual assemblages $(C)$ and their distribution in lithotypes $(F)$;

statistical reliability of the non-metric multidimensional scaling is expressed by a Shepard plot (E) 
7. The worst preservation of nannofossils and the lowest diversity characterize two samples with only large nannofossils from "Peškova stráň" (Fig. 7).

The distribution of assemblages in individual lithotypes shows no correlation between the lithotype and type of assemblage (Fig. 7F).

\section{INTERPRETATION AND DISCUSSION}

\section{BIOSTRATIGRAPHY}

The stratigraphical ranges of the species determined are summarized in Appendix 1 and Figure 8, using mainly data from
Young et al. (2014) and Gradstein et al. (2012). Since there was no continuous section sampled, the stratigraphic succession of the samples is unknown. Therefore, the maximum biostratigraphical range was determined for each individual sample (Appendix 1) and the duration of the marine Jurassic sedimentation in Northern Bohemia were synthesized from these data (Fig. 8).

Three intervals of the maximum possible time of Jurassic sedimentation were determined from calcareous nannoplankton ranges. However, the real time of marine incursion might have been shorter.

1. Most samples contain only long-range taxa ranging from the NJ9 to NJ12 zones through the top of the Jurassic or the Lower Cretaceous. Sporadically occurring species with their last occurrence in the $\mathrm{NJ} 15$ Zone (Lotharingius sigillatus;

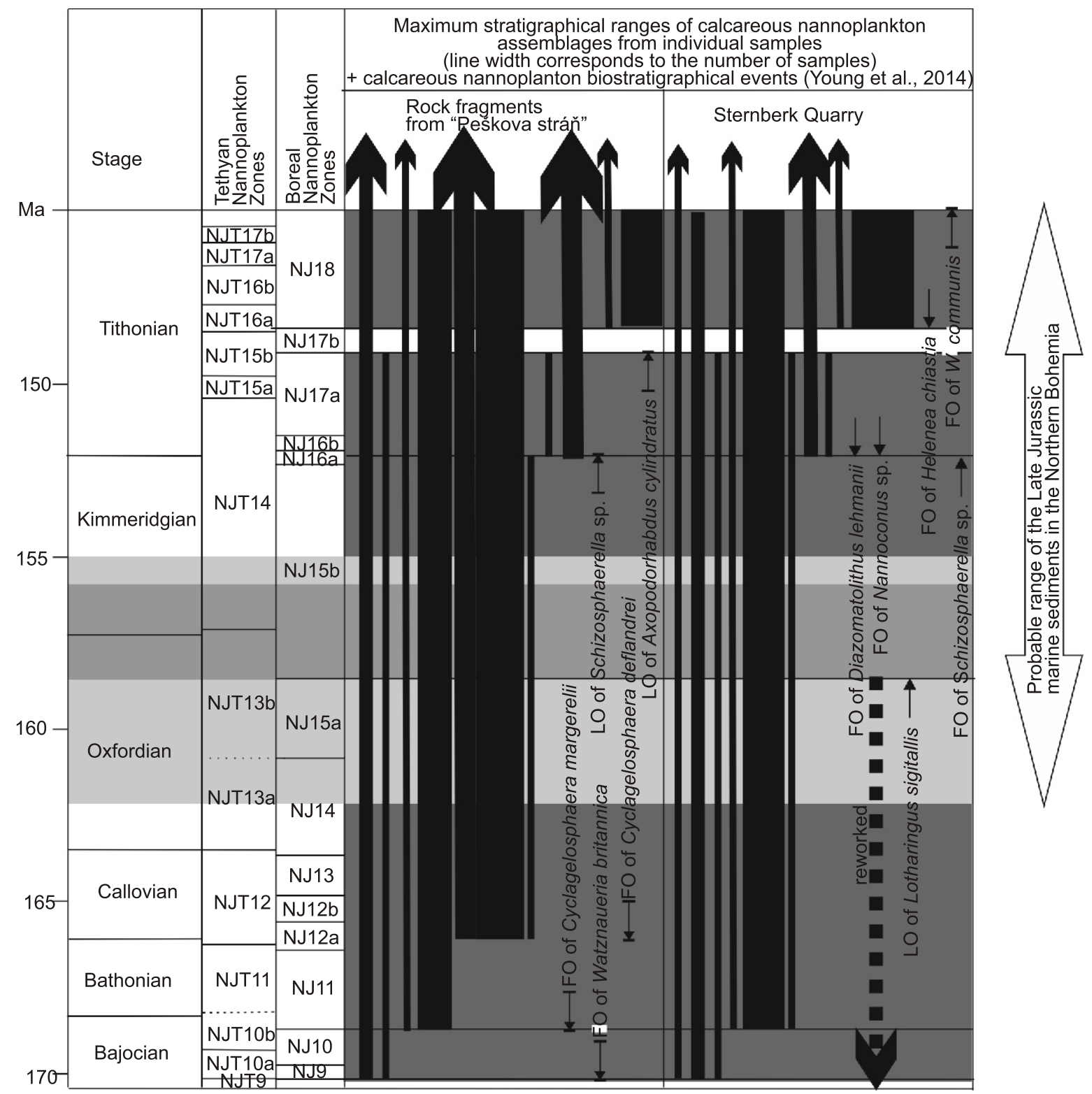

the maximum possible stratigraphical range of calcareous nannoplankton assemblages

the interval with the highest density of fauna (Hrbek, 2014)

maximal stratigraphical range of ammonites from the Northern Bohemia (Hrbek, 2011)

Fig. 8. Maximum biostratigraphical ranges of the Northern Bohemia Jurassic deposits based on calcareous nannoplankton 
Schizosphaerella sp.) indicate that the depositional history must have started before the NJ15 Zone if these species are not reworked.

Within this interval is possible to include the range of determined ammonite zones of Cardioceras cordatum to Ataxioceras hypselocyclum (Hrbek, 2014), which can be correlated with nannoplankton zones from the upper part of NJT13a to the middle part of NJT14 (Tethyan zonation) or from NJ14 to the middle part of NJ15b (Boreal zonation; Gradstein et al., 2012). Unfortunately, the high-latitude and fragile genus Stephanolithion, significant for biostratigraphical correlation in this interval, is missing. The reasons could be palaeogeographic and palaeoecological (lack of suitable palaeoenvironment in the North Bohemian Basin or along the connecting seaways) and/or taphonomic (destruction or dissolution of fragile nannofossils).

2. Co-occurrence of Diazomatolithus lehmanii and Axopodorhabdus cylindratus in rock fragments from "Peškova strán"” indicates a Tithonian age. However, neither of the species is an important biostratigraphic marker, therefore this correlation might not be entirely reliable.

3. Samples with Helenea chiastia and nannoconids indicate a mid-Tithonian age (Casellato, 2010; Gradstein, 2012).

The stratigraphical ranges (2) and (3) have extended the age of Jurassic deposits in the Northern Bohemia as determined from ammonites (Hrbek, 2014). Isochronous deposits are known from autochthonous Jurassic sequences in the eastern part of the Bohemian Massif (Adámek, 2005) and central Poland (Kutek and Zeiss, 1997; Gaździcka, 1998; Kin et al., 2013). This suggests that the Northern Bohemia could have represented a communication corridor between Boreal and Sub-Boreal areas and the Tethyan Realm up until the latest Jurassic.

\section{PALAEOECOLOGY}

The prevailing genus Watznaueria seems to be ubiquitous and dominant during the mid-Jurassic-Late Cretaceous, especially within the low and middle palaeolatitudes in different areas of the Tethys Ocean, as well as e.g. in the Central Atlantic and on the Russian Platform (Street and Bown, 2000; Bornemann et al., 2003; Lees et al., 2004, 2006; Giraurd et al., 2006; Ustinova, 2009; Kędzierski, 2012; Colombié et al., 2014). The genus is considered to be a cosmopolitan form, dissolution-resistant, indicating more oligotrophic surface water nutrient levels (e.g., Roth and Krumbach, 1986; Premoli-Silva et al., 1989; Williams and Bralower, 1995; Pittet and Mattioli, 2002; Bornemann et al., 2003). In contrast, Lees et al. (2004, 2006) explained the high abundance of low-diversity assemblages dominated by watznaueriaceans as a response to nutrient-rich environments from which non-watznaueriacean taxa were ecologically excluded. In any case, watznaueriaceans represent a eurytopic life strategy with wide palaeoecological tolerance, and all prevailing species $-W$. britannica, $W$. barnesiae/fossacincta and Cyclosphaera margerelii could live in unstable environments (Lees et al., 2004, 2006; Columbié et al., 2014).

Though seven calcareous nannoplankton assemblages were distinguished in Northern Bohemia (Fig. 7), the species composition characterizing these assemblages is very similar and no nannoplankton changes known from the Late Jurassic have been clearly recorded here. These changes may reflect nutrient oscillations, for example in increase of markers of high nutrient levels such as Biscutum constans, Discorhabdus ignotus and Zeugrhabdotus erectus in the Early Tithonian (e.g., Premoli-Silva et al., 1989; Coccioni et al., 1992; Erba et al., 1992; Bornemann et al., 2003). Similarly in the Volgian
(=Tithonian) sequence of the Russian Platform, a succession of Watznaueria barnesiae-W. fossacincta acme, followed by a $W$. britannica-W. communis acme Zeugrhabdotus erectus and Biscutum constans acme have been interpreted as a transition from a warmer, oligotrophic setting to a cooler, eutrophic one (Kessels et al., 2003). On the other hand, increase in relative abundance of Schizosphaerella punctulata recorded in the latest Oxfordian-earliest Kimmeridgian of SW Germany was correlated with a shift from humid conditions in the earliest Late Oxfordian to a drier and warmer climate in the earliest Kimmeridgian (Bartolini et al., 2003). Similarly the 'Nannofossil Calcification Event' (NCE) with mass occurrences of strongly calcified taxa Conusphaera mexicana, Polycostella beckmannii, Nannoconus spp., Watznaueria cf. manivitae recognized in the mid-Tithonian was caused by aridification, oligotrophic surface water conditions and lower atmospheric $\mathrm{pCO}_{2}$ (Bornemann et al., 2003).

The absence of these events in Northern Bohemia may be explained by both diagenetic alteration of assemblages in which only dissolution-resistant Watznaueria were preserved (Roth and Krumbach, 1986; Bornemann et al., 2003) or primarily by specific palaeoecological conditions. Dissolution may have played a role in low-diversity assemblages composed mainly of large, badly preserved heterococcolithus (assemblages dominated by $W$. britannica and assemblages of large coccoliths; Fig. 7). Other assemblages more probably reflect the existence of specific but stable conditions during the Late Jurassic in North Bohemia. For detailed interpretation of palaeoecological variability in the Northern Bohemia Jurassic sea, the ratio between (1) Watznaueria britannica - (2) the W. fossacincta/W. barnesiae group - (3) large W. manavitiae and (4) Cyclagelosphaera margerelii were used. Variation in this ratio defines the six assemblages (Fig. 7).

1. The assemblage dominated by $W$. britannica is the most diverse in Northern Bohemia and contains the best preserved nannofossils. This, together with the highest abundances of small watznaueriaceans (14\%), indicates low to no diagenetical alternation of assemblages. Therefore the assemblage may be easily used for palaeoecological interpretation. The palaeoecological preferences of $W$. britannica were suggested by many authors, as follows Lees et al. (2004) described adaptation of the species to high nutrient concentrations; Giraud et al. (2006) showed that the environmental preferences of $W$. britannica vary with morphometrical variance: increasing sizes are associated with a lowering of the trophic level and warm climatic conditions; this was also suggested by Olivier et al. (2004) who noted that small $W$. britannica preferred high mesotrophic environments, whereas large $W$. britannica were oligotrophic; Carcel et al. (2010) also described a dominance of the smallest morphotype of $W$. britannica in higher trophic conditions. In Northern Bohemia, medium-sized specimens $(5.5-6.5 \mu \mathrm{m})$ prevailed, which could correspond with low mesotrophic conditions. Such conditions possibly represent the highest trophic level in the study area. Moreover, this interpretation is supported by high abundances of other small watznaueriaceans. The $W$. britannica assemblage has been recorded only in samples from the former Šternberk Quarry which might suggest that this famous palaeontological locality yields deposits representing the higher nutrient palaeoconditions.

2. A low-diversity assemblage with abundant $W$. britannica accompanied by $W$. barnesiae and $W$. fossacincta, together with the absence of small watznaueriaceans, suggests that it is a diagenetically affected assemblage (1). Both assemblages occur only in the former Šternberk Quarry.

3. An assemblage dominated by $W$. barnesiae and $W$. fossacincta as end-members of a morphological continuum 
(Lees et al., 2004, 2006; Bornemann and Mutterlose, 2006) is characteristic of rock fragments from "Peškova stráň". The assemblage reached moderate diversity (4-5 species) and nannofossils are rarely well or, more commonly, moderately preserved. According to Roth and Krumbach (1986), W. barnesiae-dominated assemblages are indicators of dissolution which could correspond with low diversity and moderate preservation of nannofossils in Northern Bohemia. On the other hand the presence of small coccoliths liable to dissolution rather supports an original composition of assemblages. Mutterlose (1989) and Mutterlose and Wise (1990) recorded high abundances of $W$. barnesiae in restricted, shallow-water settings. $W$. barnesiae seems to have been an ecologically robust form that could tolerate a wide range of extreme biotopes and was one of the pioneer species to settle in new biotopes (Mutterlose, 1991). W. barnesiae is generally interpreted as indicative of oligotrophy (Erba, 1992; Erba et al., 1992; Williams and Bralower, 1995; Pittet and Mattioli, 2002; Herrle, 2003 Bornemann et al., 2003; Mutterlose et al., 2005) and the abundances of $W$. barnesiae are in "phase opposition" with eutrophic taxa such as Z. erectus and B. constans (Erba et al., 1992; Herrle, 2003). In contrast, Lees et al. (2004) concluded that $W$. fossacincta/barnesiae occupied a more eutrophic position than $W$. britannica, although later the same authors stated that $W$. fossacincta/barnesiae assemblages indicate slightly less nutrients by comparison with $W$. britannica assemblages (Lees et al., 2006).

To summarize these inconsistencies, the assemblage (2) type represents a generally oligotrophic environment with seasonal and/or interannual oscillations of ecological parameters including nutrients and salinity. The influence of diagenetic effects cannot be excluded.

4. A Watznaueria spp.-Cyclagelosphaera margerelii-only assemblage occurs both in fragments from "Peškova stráñ" as well as from Šternberk Quarry. C. margerelii became dominant in neritic and/or restricted environments (Bown, 2005; Giraud et al., 2005; Carcel et al., 2010). Busson et al. (1992, 1993) have described assemblages composed essentially of $C$. margerelii and $W$. britannica in a Late Jurassic restricted-lagoon environment, possibly receiving fresh-water influxes. Monospecific assemblages formed of $C$. margerelii characterize Kimmeridgian strata deposited in a lagoonal environment with significant salinity variations (Tribovillard et al., 1992). Street and Bown (2000) and Bown et al. (2004) argued that C. margerelii was a neritic taxon. Lees et al. (2006) considered C. margerelii to be the most extremely r-selected species, exploiting unusual conditions. Generally, this assemblage may represent an unstable marginal environment, e.g. with salinity oscillations.

5. A diverse assemblage composed of well-preserved nannofossils occurs in rock fragments from "Peškova stráń". Besides watznaueriaceans (excluding W. britannica), Diazomatolithus lehmanii, large Cyclagelosphaera deflandrei and Nannoconus sp. may appear here but only in low abundances, while small watznaueriaceans are common. Assemblages can be correlated with the Tithonian, and may represent a slight influence of Tithonian events, both increase of nutrients (occurrence of the high-nutrient marker Diazomatolithus lehmanii: Roth, 1981; Roth and Bowdler, 1981; Roth and Krumbach, 1986; Premoli-Silva et al., 1989; Coccioni et al., 1992; Erba, 1992; Williams and Bralower, 1995; Mattioli and Pittet, 2004) and a 'Nannofossil Calcification Event' (occurrence of Nannoconus sp.).

6. Assemblages dominated by $W$. communis and an assemblage only with large nannofossils contains the worst-preserved nannofossil specimens and reached the lowest diversity. Both these assemblages are taphonomically affected and do not provide palaeoecological information.

\section{PALAEOGEOGRAPHY}

Provincialism of Late Jurassic calcareous nannofossils is well known and has been clearly documented (Cooper, 1989; Mutterlose and Kessels, 2000; Street and Bown, 2000). However, the Bathonian-Kimmeridgian interval is characterized by the dominance of the genus Watznaueria in both Boreal and Tethyan provinces (Busson et al., 1992; Bown and Cooper, 1998; Pittet and Mattioli, 2002; Olivier et al., 2004; Lees, 2004 , 2006, Tremolada et al., 2006) as well as in Northern Bohemia. Only a few individuals record directions of nannoplankton migrations through the Northern Bohemian corridor.

Generally, Tethyan taxa migrated to the Boreal province when seaways, sea-level and surface temperatures became suitable (Mutterlose, 1989; Mutterlosse et al., 2005) and vice-versa: the cold-water Boreal taxa may have penetrated to Tethys during cooling episodes, while warm-water nannoplankton migrated to the north during warm periods. Therefore, palaeotemperature trends are decisive for direction of migration. For reconstruction of palaeotemperature trends in the Late Jurassic a coincidence of the bulk O-isotope curve (Weissert and Erba, 2004) with trends reconstructed with palynological information from northern Europe by Abbink et al. (2001) was used. They described the mid-Oxfordian warming contrasting with the cool Early and Late Oxfordian and Early Kimmeridgian following by a long-term warming trend lasting from the Kimmeridgian into the earliest Cretaceous. Moreover, Tremolada et al. (2006) described a cooling episode at the Callovian-Oxfordian boundary.

The Northern Bohemian Oxfordian-Kimmeridgian assemblages are low-diversity and contain only watznaueriaceans. The high-latitude genus Stephanolithion is lacking and assemblages reflect an unstable, marginal environment without markers of migration direction. However, Hrbek (2014) described an equatorward migration of cold-water ammonites close to the Oxfordian-Kimmeridgian boundary which may reflect Oxfordian-Kimmeridgian cooling.

Episodic migrations of the Tethyan genus Nannoconus into the Boreal Realm known from the Valanginian, Hauterivian and mid-Aptian were used to reconstruct global changes in temperature and sea-level (Mutterlosse et al., 2005). The occurrence of Tethyan taxa in the Tithonian samples in Northern Bohemia indicates a south-north direction of migration in agreement with warming towards the Jurassic-Cretaceous boundary.

\section{CONCLUSIONS}

1. Calcareous nannoplankton was found in Jurassic relicts in Northern Bohemia. The calcareous nannoplankton assemblages studied are generally of low diversity, dominated by watznaueriaceans and some of them are diagenetically affected.

2. The degree of diagenetic alternation does not correspond with lithotypes recognize so far and probably corresponds with the degree of dolomitisation induced by Cenozoic tectonic activity in the Lusatian tectonic zone and by Cenozoic volcanism. Therefore, strongly dolomitised Jurassic strata are not promising for further nannoplankton studies.

3. The first time of Jurassic marine incursion to the Northern Bohemia cannot be exactly dated by calcareous nannoplankton, and can be better determined by ammonites. However, calcareous nannoplankton allows determination of the duration of the North Bohemian sea corridor to the Tithonian.

4. The Oxfordian-Kimmeridgian assemblages dominated by Watznaueria fossacincta/barnesiae community show a rather oligotrophic condition of a restricted sea. However, epi- 
sodic instability triggered probably by seasonal and/or interannual freshwater input may have taken place. Generally, the palaeoenvironment of the superficial water was uniform and did not reflect variability at the sea-floor expressed by lithofacies variance.

5. Specific assemblages dominated by Watznaueria britannica characterize the former palaeontological locality "Šternberk Quarry" and indicate higher nutrient contents and a more stable environment. The degree of diagenetic alternation is low in this case.

6. The Tithonian assemblages exhibit high diversity and contain warm-water Tethyan taxa. This suggests migration of Tethyan taxa to the Boreal-Subboreal Province, probably due to temperature increase towards the Jurassic-Cretaceous boundary.

Acknowledgements. We thank J. Hrbek, M. Košták A. Svobodová (Charles University in Prague) and J. Sklenár (National Museum Prague), for useful discussions and suggestions during the preparation of this manuscript, J. Hrbek and M. Košták, for their help with field collections and J. Sklenář for sampling in the National Museum in Prague collection. The constructive reviews of E. Halásová and M. Kędzierski substantially improved the manuscript. The authors greatly appreciate the work of the editor T. Peryt on the final form of the manuscript. The study was supported by the project PRVOUK P44.

\section{REFERENCES}

Abbink, O., Targarona, J., Brinkhuis, H., Visscher, H., 2001. Late Jurassic to earliest Cretaceous paleoclimatic evolution of the southern North Sea. Global and Planetary Change, 30: 231-256.

Adámek, J., 2005. The Jurassic floor of the Bohemian Massif in Moravia - geology and paleogeography. Bulletin of Geosciences, 80: 291-305.

Alexandrowicz, Z., 1999. Representative geosites of Central Europe. Polish Geological Institute Special Papers, 2: 9-14.

Atrops, F., Enay, R., Meléndez, G., 1993. Joint meeting of the Oxfordian and Kimmeridgian working groups, Warsaw, Poland, September 7-12, 1992. Acta Geologica Polonica, 43: 157-168.

Bartolini, A., Pittet, B., Mattioli, E., Hunziker, J.C., 2003. Shallow-platform palaeoenvironmental conditions recorded in deep-shelf sediments: $\mathrm{C}$ and $\mathrm{O}$ stable isotopes in Upper Jurassic sections of southern Germany (Oxfordian-Kimmeridgian). Sedimentary Geology, 160: 107-130.

Bornemann, A., Mutterlose, J., 2006. Size analyses of the coccolith species Biscutum constans and Watznaueria barnesiae from the Late Albian "Niveau Breistroffer" (SE France): taxonomic and paleoecological implications. Geobios, 39: 599-615.

Bornemann, A., Aschwer, U., Mutterlose, J., 2003. The impact of calcareous nannofossils on the pelagic carbonate accumulation across the Jurassic-Cretaceous boundary. Palaeogeography, Palaeoclimatology, Palaeoecology, 199: 187-228.

Bown, P.R., 2005. Selective calcareous nannoplankton survivorship at the Cretaceous-Tertiary boundary. Geology, $\mathbf{3 3}$ 653-656.

Bown, P.R., Cooper, M.K.E., 1998. Jurassic. In: Calcareous Nannofossil Biostratigraphy (ed. P.R. Bown): 34-85. British Micropalaeontological Society Series, Kluwer Academic Press, Dordrecht.

Bown, P.R., Lees, J.A., Young, J.R., 2004. Calcareous nannoplankton evolution and diversity through time. In: Coccolithophores. From Molecular Processes to Global Impact (eds. H.R. Thierstein and J.R. Young): 481-508. Springer, Berlin.

Bruder, G., 1881. Zur Kenntniss der Juraablagerung von Sternberg bei Zeidler in Böhmen, mit 2 Tafeln. Sitzungsberichte der Kaiserlichen Akademie der Wissenschaften, 83: 43-47.

Bruder, G., 1882. Neue Beitrage zur Kenntniss der Juraablagerungen im nördlichen Böhmen mit 3 Tafeln. Sitzungsberichte der Kaiserlichen Akadademie der Wissenschaften, 85: 442-449.

Bruder, G., 1885. Die Fauna der Juraablagerung von Hohnstein in Sachsen, 1-6. K.K. Hofund Staatsdruckerei, Wien.
Bruder, G., 1886. Neue Beitrage zur Kenntniss der Juraablagerungen im nördlichen Böhmen II., mit 1 Tafel und 1 Holzschnitt. Sitzungsberichte der Kaiserlichen Akademie der Wissenschaften, 93: 193-216.

Busson, G., Noel, D., Cornée, A., 1992. Les coccolithes en boutons de manchette et la genese des calcaires lithographiques du Jurassique superieur. Revue de Paleobiologie, 11: 255-271.

Busson, G., Noel, D., Contini, D., Mangin, A.-M., Corne.e, A., Hantzpergue, P., 1993. Omnipresence de coccolithes dans des calcaires lagunaires du Jurassique moyen et superieur de France. Bulletin du Centre de Recherches Elf Exploration Production Aquitaine, 17: 291-301.

Carcel, D., Colombie, C., Giraud, F., Courtinat, B., 2010. Tectonic and eustatic control on mixed siliciclastic-carbonate platform during the Late Oxfordian-Kimmeridgian (La Rochelle platform, western France). Sedimentary Geology, 223: 334-359.

Casellato, C.E., 2008. Causes and consequences of calcareous nannoplankton evolution in the Late Jurassic: implications for biogeochronology, biocalcification and ocean chemistry. Ph.D. thesis. Università degli Studi di Milano.

Casellato, C.E., 2010. Calcareous nannofossil biostratigraphy of Upper Callovian-Lower Berriasian successions from Southern Alps, North Italy. Rivista Italiana di Palaeontologia e Stratigrafia, 116: 357-404

Chlupáč, I., Štorch, P., 1992. Regionálně geologické dělení Českého masívu na území České republiky (in Czech). Časopis pro Mineralogii a Geologii, 37: 258-275.

Chlupáč, I., Brzobohatý, R., Kovanda, J., Stráník, Z., 2002. Geological history of Czech Republic (in Czech). Academia, Prague.

Coccioni, R., Erba, E., Premoli-Silva, I., 1992. Barremian-Aptian calcareous plankton biostratigraphy from the Gorgo a Cerbara section (Marche, Central Italy) and implications for plankton evolution. Cretaceous Research, 13: 517-537.

Colombié, C., Giraud, F., Schnyder, J., Götz, A., Boussaha, M., Aurell, M., Bádenas, B., 2014. Timing of sea level, tectonics and climate events during the uppermost Oxfordian (Planula Zone) on the Iberian ramp (northeast Spain). Palaeogeography, Palaeoclimatology, Palaeoecology, 412: 17-31.

Cooper, M.K.E., 1989. Nannofossil provincialism in the Late Jurassic-Early Cretaceous (Kimmeridgian to Valanginian) period. In: Nannofossils and their Applications (eds. J.A. Crux and S.E. Van Heck): 223-246. Chichester.

Eliáš, M., 1981. Facies and paleogeography of the Jurassic of the Bohemian Massif. Sborník geologických věd. Řada G, Geologie, 35: 75-144. 
Erba, E., 1992. Calcareous nannofossil distribution in pelagic rhythmic sediments (Aptian-Albian Piobbico Core, Central Italy). Rivista Italiana di Palaeontologia e Stratigrafia, 97: 455-484.

Erba, E., Castradori, D., Guasti, G., Ripepe, M., 1992. Calcareous nannofossil and Milankovitch cycles: the example of the Albian Gault Clay Formation (southern England). Palaeogeography, Palaeoclimatology, Palaeoecology, 93: 47-69.

Gaździcka, E., 1998. Upper Jurassic. In: Paleogeographical Atlas of the Epicontinental Permian and Mesozoic in Poland (eds. R. Dadlez, S. Marek and J. Pokorski). Państw. Inst. Geol. Warszawa.

Giraud, F., Courtinat, B., Garcia, J.-P., Baudin, F., Guillocheau, F., Dromart, G., Atrops, F., Collete, C., 2005. Palynofacies and calcareous nannofossils in the Upper Kimmeridgian, southeastern Paris basin (France). Bulletin Société Géologique de France, 176: 457-466.

Giraud, F., Pittet, B., Mattioli, E., Audouin, V., 2006 Paleoenvironmental controls on the morphology and abundance of the coccolith Watznaueria britannica (Late Jurassic southern Germany). Marine Micropaleontology, 60: 205-225.

Gradstein, F.M., Ogg, J.G., Schmitz, M.D., Ogg, G.M., 2012. The Geologic Time Scale 2012, 2. Volume Set. Elsevier, New York.

Hammer, Ø., Harper, D.A.T., Ryan, P.D., 2001. PAST: Paleontological Statistics Software Package for Education and Data Analysis. Palaeontologica Electronica, 4: 1-9.

Herrle, J.O., 2003. Reconstructing nutricline dynamics of mid-Cretaceous oceans: Evidence from calcareous nannofossils from the Niveau Paquier black shale (SE France). Marine Micropaleontology, 47: 307-321.

Hrbek, J., 2014. The systematics and paleobiogeographic significance of Sub-Boreal and Boreal ammonites (Aulacostephanidae and Cardioceratidae) from the Upper Jurassic of the Bohemian Massif. Geologica Carpathica, 65: 375-386.

Kędzierski, M., 2012. Calcareous nannofossils from the Bathonian (Middle Jurassic) ore-bearing clays at Gnaszyn as palaeoenvironmental indicator, Kraków-Silesia Homocline, Poland. Acta Geologica Polonica, 62: 421-437.

Kessels, K., Mutterlose, J., Ruffell, A., 2003. Calcareous nannofossils from late Jurassic sediments of the Volga Basin (Russian Platform): evidence for productivity controlled black shale deposition. International Journal of Earth Sciences, 92: 743-757.

Kin, A., Gruszczyński, M., Martill, D., Marshall, J.D., Błażejowski, B., 2013. Palaeoenvironment and taphonomy of a Late Jurassic (Late Tithonian) Lagerstätte from central Poland. Lethaia, 46: 71-81.

Kopecký, L., Bůžek, Č., Dvořák, J., Fejfar, O. Gabrielová-Bořková, N., Hirschmann, G., Chaloupský, J., Jetel, J., Kaiser, T., Líbalová, J., Louček, D., Řeháková, Z., Sattran, V., Soukup, J., Svoboda, J., Štemprok, M., Škvor, V., Václ, J. 1963. Explanations of the geological map 1:200,000 Děčín (in Czech). Úst. Úst. Geol., Československá akademie věd, Prague.

Kutek, J., Zeiss, A., 1997. The highest Kimmeridgian and Lower Volgian in Central Poland; their ammonites and biostratigraphy. Acta Geologica Polonica, 47: 107-198.

Lees, J.A., Bown, P.R., Young, J.R., Riding, J.B., 2004. Evidence for annual records of phytoplankton productivity in the Kimmeridge Clay Formation coccolith stone bands (Upper Jurassic Dorset, UK). Marine Micropaleontology, 52: 29-49.

Lees, J.A., Bown, P.R., Young, J.R., 2006. Photic zone palaeoenvironments of the Kimmeridge Clay Formation (Upper Jurassic, UK) suggested by calcareous nannoplankton palaeoecology; causes and consequence of marine organic carbon burial through time. Palaeogeography, Palaeoclimatology, Palaeoecology, 235: 110-134.

Lenz, O., 1870. Über das Auftreten jurassischer Gebilde in Böhmen Zeitschrift für Naturwissenschaften, 35: 337.
Mattioli, E., Pittet, B., 2004. Spatial and temporal distribution of calcareous nannofossils along a proximal-distal transect in the Umbria-Marche basin (Lower Jurassic; Italy). Palaeogeography, Palaeoclimatology, Palaeoecology, 205: 295-316.

Matyja, B.A., Wierzbowski, A., 1994. On correlation of Submediterranean and Boreal ammonite zonations of the Middle and Upper Oxfordian: new data from central Poland. Geobios, 27: 351-358.

Matyja, B.A., Wierzbowski, A., 1995. Biogeographic differentiation of the Oxfordian and Early Kimmeridgian ammonite faunas of Europe, and its stratigraphic consequences. Acta Geologica Polonica, 45: 1-8.

Matyja, B.A., Wierzbowski, A., 2000. Biological response of ammonites to changing environmental conditions: an example of Boreal Amoeboceras invasions into Submediterranean Province during Late Oxfordian. Acta Geologica Polonica, 50: 45-54.

Mutterlose, J., 1989. Temperature-controlled migration of calcareous nannofloras in the north-west European Aptian. In: Nannofossils and their Applications (eds. J.A. Cruxand and S.C. Van Heck): 122-142. Chichester (Ellis Horwood).

Mutterlose, J., 1991. Das Verteilungs und Migrationsmuter des kalkigen Nannoplanktons in der borealen Unterkreide (Valangin-Apt). Paläontographica, B 221: 27-152.

Mutterlose, J., Kessels, K., 2000. Early Cretaceous calcareous nannofossils from High latitudes: implications for paleobiogeography and paleoclimate. Palaeogeography, Palaeoclimatology, Palaeoecology, 160: 347-372.

Mutterlose, J., Wise, S.W. jr., 1990. Lower Cretaceous nannofossil biostratigraphy of ODP LEG 113 Holes 692B and 693A, continental slope off east Antarctica, Weddell Sea. Proceedings of the Ocean Drilling Program, Scientific Results, 113: 325-351.

Mutterlose, J., Bornemann, A., Herrle, J.O., 2005. Mesozoic calcareous nannofossils - state of the art. Paläontologische Zeitschrift, 79: 113-133.

Olivier, N., Pittet, B., Mattioli, E., 2004. Palaeoenvironmental control on spongemicrobialite reefs and contemporaneous deep-shelf marl-limestone deposition (Late Oxfordian, southern Germany). Palaeogeography, Palaeoclimatology, Palaeoecology, 212: 233-263.

Pittet, B., Mattioli, E., 2002. The carbonate signal and calcareous nannofossil distribution in an Upper Jurassic section (Balingen-Tieringen, Late Oxfordian, and southern Germany). Palaeogeography, Palaeoclimatology, Palaeoecology, 179: 71-96

Premoli-Silva, I., Erba, E., Tornaghi, M.E., 1989 Paleoenvironmental signals and changes in surface water fertility in mid Cretaceous Corg-rich pelagic facies of the Fucoidi Marls (Central Italy). Geobios Memoire Special, 11: 225-236.

Roth, P.H., 1981. Mid Cretaceous calcareous nannoplankton from the Central Pacific: implications for paleoceanography. Initial Reports Deep Sea Drilling Project, 62: 471-489.

Roth, P.H., 1983. Jurrassic and Lower Cretaceous calcareous nannofossil in the Western North Atlantic (534): biostratigraphy, presenvation, and some observation on biogeography and paleoceanography. Initial Reports Deep Sea Drilling Project, 76: 587-621.

Roth, P.H., Bowdler, J.L., 1981. Middle Cretaceous calcareous nannoplankton biogeography and graphy of the Atlantic Ocean. SEPM Special Publication, 32: 517-546.

Roth, P.H., Krumbach, K.R., 1986. Middle Cretaceous calcareous nannofossil biogeography and preservation in the Atlantic and Indian oceans: implications for palaeoceanography. Marine Micropalaeontology, 10: 235-266.

Street, C., Bown, P.R., 2000. Palaeobiogeography of Early Cretaceous (Berriasian-Barremian) calcareous nannoplankton. Marine Micropalaeontology, 39: 265-291.

Suk, M., 1984. Geological history of the territory of the Czech Socialist Republic. Geological Survey, Prague. 
Tremolada, F., Bornemann, A., Bralower, T.J., Koeberl, C., van de Schootbrugge, B., 2006. Paleoceanographic changes across the Jurassic/Cretaceous boundary: the calcareous phytoplankton response. Earth and Planetary Science Letters, 241: 361-371.

Tribovillard, N.P., Gorin, G., Belin, S., Hopfgartner, G., Pichon, R., 1992. Organic-rich biolaminated facies from a Kimmeridgian lagoonal environment in the French Southern Jura Mountains. A way of estimating accumulation rate variations. Palaeogeography, Palaeoclimatology, Palaeoecology, 99: 163-177.

Ustinova, M.A., 2009. The distribution of calcareous nannofossils and foraminifers in the Callovian, Oxfordian, and Volgian depos- its in the southwest of Moscow. Stratigraphy and Geological Correlation, 17: 204-217.

Weissert, H., Erba, E., 2004. Volcanism, $\mathrm{CO}_{2}$ and palaeoclimate: a Late Jurassic-Early Cretaceous carbon and oxygen isotope record. Journal of the Geological Society, 161: 695-702.

Williams, J.R., Bralower, T.J., 1995. Nannofossil assemblages, fine fraction stable isotopes, and the paleoceanography of the Valanginian-Barremian (Early Cretaceous) North Sea Basin. Paleoceanography, 10: 815-839.

Young, J.R., Bown, P.R., Lees, J.A., eds., 2014. Nannotax3 website. International Nannoplankton Association. 21 Apr. 2014. URL: http://ina.tmsoc.org/Nannotax3/ 